\title{
Oprøret i Iran lever i det stille
}

\section{Vibeke Sperling}

\section{Der kaldes til 'stille demonstrationer', imens regimet er mere splittet end nogensinde siden den islamiske revolution i 1979}

Det var set i bakspejlet en overdosis af håb, som iranere fik op til præsidentvalget 12. juni 2009. I stedet for at blive et foregangsoprør i den muslimske verden blev iranernes håb tromlet ned i den omgang.

På toårsdagen for præsidentvalget, som fik millioner af iranere i gaderne til verdens forbløffelse, var der kaldt til "stille demonstration" i Teheran og andre iranske byer. Ifølge oppositionens websider slog politiet hårdt ned imod 'de stille'. Hundredvis blev arresteret alene på Vali Asr gaden i Teheran, som var centrum for flere dages gadefest op til valget for to år siden. Dengang blev der danset for en forventet sejr for den reformorienterede kandidat MirHussein Mousavi. Men mens arabiske oprørere siden har afsat flere af deres ledere, som nu retsforfølges, har Mousavi længe været i husarrest uden dom for noget.

Et vidne sagde på toårsdagen til
Radio Free Europe: "Som ventet stod store specialstyrker som en menneskemur på begge sider af Vali Asr. Folk ignorerede dem og gik videre på fortovene, men uden at synge som for to år siden".

Irans ledelse har prist arabiske demonstrationer, men banket egne borgere væk fra gaderne. På en pressekonference i Washington ved årsdagen sagde oppositionsleder Mir-Hussein Mousavis talsmand, Ardeshir Amir Arjomand, at regeringen ikke har formået at gøre Den Grønne Bevægelse tavs. Bevægelsen blev skabt imod valgsvindel i 2009 og "har nok ændret taktik som svar på den barske undertrykkelse, men den har fundet en vej til at forblive i live".

I 2009 så arabere med beundring på iranernes mod, da de gik i gaderne for at kræve deres ret. "Mange arabiske kommentatorer som jeg selv skrev om, hvorfor det kunne ske 
i Iran, men ikke i arabiske stater. Vi stillede spørgsmålet, hvad der skulle til for, at arabere kunne efterligne det iranske eksempel", skriver den amerikansk-libanesiske kommentator Hussein Ibish.

Regimet har formået at slå opstanden tilbage for nu, men det er i åben strid med sig selv. Bloggeren Alireza Jafarzadeh skriver, at hvedebrødsdagene synes ovre for præsident Mahmoud Ahmedinejad, der er i konflikt med den Øverste Leder Ali Khamenei. I april røg de uklar om fyring og udnævnelse af ministre. Præsidenten søgte at rense ud omkring sig med en sjælden offentlig opposition fra Khamenei til følge.

"Den skærpede splittelse er et vendepunkt for et regime, der kun overlever med undertrykkelse og rå magt. Regimet har ikke været i stand til at udradere den sociale modstand, endsige løse sin interne krise. Som resultat er Khameneis autoritet gradvist undergravet, og det har givet Ahmadinejad mulighed for at kræve mere indflydelse", skriver Jafarzadeh.

Den iranske filosof i eksil i Canada, Ramin Jahanbegloo, skriver i en artikel i Christian Science Monitor, at det umiddelbart er Ahmadinejad, som står til at tabe den magtkamp:

"Ahmadinejad har begået samme fejltagelse som tidligere præsident Abolhassan Bani Sadr for 30 år siden, da denne blev tvunget i eksil, fordi han udfordrede den $\emptyset$ verste Leder. Denne gang kommer udfor- dringen fra den dobbelte autoritet, som forfatningen foreskriver".

Forfatningen giver overhånd til sharia, 'den guddommelige vilje', men med valg til parlamentet og præsidentposten inkorporerer den også folkets vilje. Opstanden i 2009 tog udgangspunkt i netop borgernes forfatningsmæssige ret, da millioner råbte: "Hvor er min stemme?". Jahanbegloo, en af Irans bedst kendte dissidenter, fremhæver, at prisen for at tale magten midt imod har været langt højere end ventet: "Massearrestationer, stalinismelignende skueprocesser, tortur, voldtægter og mord. Og selve det iranske system med magten delt mellem præsidenten og den Øverste Leder har kompliceret og forsinket forandringsprocessen".

Men presset fra den folkelige modstand fremskynder samtidig afslutningen på Khomeinismen ved at udstille splittelserne inden for præstestyret. Protestbevægelsen har således "nået sit mål med den moralske overhånd ved at vise verden det islamiske regimes sande karakter". Det har tappet regimet "for meget af dets politiske legitimitet", ifølge Jahanbegloo.

\section{Pustet i nakken}

Et svækket regime føler sig øjensynlig pustet i nakken af omvæltningerne i hele regionen og reagerer stadig mere hidsigt udadtil og indadtil. Det er over to år siden, at USA's Ba- 
rack Obama prøvede at række hånden frem til præstestyret for at løse konflikten om Irans atomprogram, men det iranske regime har blot optrådt endnu værre siden, især over for egen befolkning.

I maj gentog IAEA's generaldirektør Yukiya Amano "bekymringer for den mulige militære dimension" af Irans atomprogram. Irans chef for atomprogrammet, Fereydoun Abbasi, sagde på en pressekonference: "Vort svar er at øge vores indsats inden for atomteknologi og knowhow." 7. juni sagde Ahmadinejad på en pressekonference: "Der er ingen bremse og intet bakgear på vores atomprogram”. På spørgsmålet om han nogensinde kan tænkes at overveje at standse uranberigelsen lød hans korte svar: "Nej".

Næste dag rapporterede Irans statslige TV, at Iran tredobler sin produktionskapacitet af højt beriget uran, og at nye, mere avancerede centrifuger vil blive installeret $\mathrm{i}$ atomfaciliteten under bjergene ved den hellige by Qom.

Alireza Jafarzadeh, forfatter til bogen The Iran Threat påpeger, at Obama har mulighed for at bidrage til både det persiske og arabiske oprør med en ny politik over for Iran. Det første skridt vil være at lette vejen for den iranske opposition.

Men hvordan ser sammenhængen egentlig ud mellem det arabiske forår, Irans Grønnes fremtid og iransk udenrigspolitik?

Tyrkiets indflydelse er øget i Mel- lemøsten i rivalisering med Iran, men uden at der er tale om fjendskab, som Tyrkiets forsøg sammen med Brasilien på at mægle i atomkonflikten har vist. Kombinationen af kappestrid og samarbejde mellem Tyrkiet og Iran er nok det eneste i Irans forhold til omverdenen, der kan bidrage til stabilitet i regionen. De to lande har tradition for at klare uenigheder ved at dæmme op for dem og undgå åben konfrontation.

Lige som demokratisering i den arabiske verden potentielt svækker det iranske regime, kan Tyrkiets stigende 'bløde magt' have samme effekt. Tyrkiets valgvinder for tredje gang, Recep Erdogan, er utvivlsomt regionens stærkeste politiske leder.

Iran forbliver en alvorlig trussel imod fred og stabilitet i regionen. Med det evige slogan 'vi støtter bevægelser imod USA og zionismen' prøver Iran at udnytte urolighederne i regionen.

På langt sigt kan begivenhederne i Mellemøsten derimod styrke mulighederne for Irans Grønne Bevægelse for at presse på for reformer, men hidtil har det kun styrket undertrykkelsen af bevægelsen.

Det er de Grønnes styrke og svaghed, at i deres meget brogede skare synes alle fraktioner enige om at undgå konfrontationer, mens de afventer, hvordan magtkampen udvikler sig.

Imod regimets påstand at arabiske oprør er del af en 'islamisk vækkelse', som gavner præstestyret, taler 
den ringe indflydelse fra islamistisk ideologi på det arabiske forår.

"Ideen om at islamister vil samarbejde på tværs af ideologiske og nationale grænser, er ikke mere realistisk end fantasien i det tidlige tyvende århundrede, at alle kommunistiske stater ville føre en fælles udenrigspolitik", skriver Hussein Ibish på sin blog.

\section{Syrien og Saudi-Arabien}

Det arabiske forår truer Irans vigtigste arabiske allierede, Syriens magthavere, på livet. Og selv Irans bedste nye mulighed for at fremme sine interesser i den arabiske verden, det shiamuslimske flertal i Bahrain, har endnu ikke leveret resultater for Teheran. Regimets egen vold imod den Grønne Bevægelse er i for frisk erindring til, at Teherans bekymring for shiamuslimers liv i Bahrain kan tages alvorligt.

Det arabiske forår har skærpet rivaliseringen og fjendskabet imellem Saudi-Arabien og Iran, der kappes om indflydelse i Syrien og Yemen. Der er kold krig, fremmet af olie og ideologi, mellem shiamuslimerne, der styrer Iran, og den sunnimuslimske saudiske kongefamilie. Og begge parter vil gerne se sig selv som ledere af verdens muslimer.

Og så er der Saudi-Arabien og Irak. Saudi-Arabien udskød i forsommeren at sende en ny ambassadør til Bagdad på grund af påstanden om, at Iraks Nour al-Malikis re- gering, der har shiitisk flertal, er for tæt på Iran. Maliki-regeringen har skabt tætte økonomiske bånd til Iran, og de to lande planlægger et regionalt sikkerhedssamarbejde, der kan øge Irans indflydelse markant i dets største arabiske naboland.

Den stigende iranske indflydelse i Irak har været længe undervejs uden sammenhæng med det arabiske forår, som Iran endnu ikke har indhøstet en eneste håndgribelig, strategisk eller stabil gevinst af.

Og foråret har givet Irans Grønne Bevægelse ny optimisme, selv om dens manøvrerum er meget mindre end for oppositionen i de fleste arabiske lande på grund af den mægtige Revolutionsgardes tilsyneladende usvækkede støtte til præstestyret.

\section{Det kan blive værre}

Problemerne med Iran kan blive endnu værre, hvis spændingerne tværs over Golfen forværres yderligere. En militær konflikt kan ikke udelukkes i Golfen, hvor en femtedel af verdens olieforsyning sejles gennem vandene mellem Saudi-Arabien og Iran. Men det store spørgsmål er, om Iran tør angribe et amerikansk protektorat.

Det skærpede fjendskab mellem Iran og Saudi-Arabien truer ikke bare hele regionen, men kan også vanskeliggøre USA's exit fra Irak i år og øge faren for et atomart våbenkapløb i regionen. På en international sikkerhedskonference i forsom- 
meren sagde prins al Faisal, tidligere leder af saudiernes efterretningstjeneste og ambassadør i blandt andet USA, at hvis Iran udvikler atomvåben, kan Saudi-Arabien føle sig tvunget til det samme.

Der har længe været ondt blod imellem Saudi-Arabien og Iran. De har reelt konkurreret om Mellem$\emptyset$ stens ressourcer siden splittelsen mellem sunnier og shiaer efter profeten Mohammeds død i 632.

Den iranske revolution i 1979 spiller stadig ind i konfliktpsyken imellem de to lande, og Saudi-Arabien har siden frygtet, at det skulle lykkes Iran at sprede sin revolution på tværs af Mellemøsten. Det så en tid ud til at kunne lykkes med store demonstrationer i Saudi-Arabiens olierige østlige provins. Og Bahrain er gammelt iransk land, som Iran krævede suverænitet over så sent som i 1970.

Saudierne blev rasende, da Obama-administrationen efter deres opfattelse svigtede deres fælles allierede Hosni Mubarak i Egypten. Han var ifølge saudierne en central del af bolværket imod iransk ekspansion. En del af bolværket var allerede brudt sammen med afsættelse af Saddam Hussein i Irak. Med tabet af Mubarak ser saudierne nu sig selv som den sidste sunni-gigant i regionen. For saudierne er urolighederne ved dets grænser ikke stemmer fra befolkningerne, men udslag af iransk indblanding.

Saudiarabiske styrkers indmarch i Bahrain 14. marts var et kritisk ven- depunkt. Siden er den regionale kolde krig skærpet. Den viser et fælles træk imellem de to kamphaner: panisk angst for demokrati.

\section{Eksempel til afskrækkelse}

Iran hævdede, at tunesere og egyptere gjorde oprør for at få deres egne varianter af den iranske revolution i 1979. Og ja, de skuede meget til Iran, men som eksempel til afskrækkelse, påpegede svensk-iranske Haideh Daragahi i en udsendelse på svensk tv i foråret. Daragahi deltog i oprøret imod Shahen og siden i kampen imod Khomeini, før hun drog i eksil.

"Egyptiske aktivister fortalte, at de interesserede sig for den iranske revolution for at undgå at gentage de politiske fejltagelser. Tunesere og egyptere har i 2011 gjort samme erfaring, som vi iranere 33 år tidligere: regimer, som forekommer at være almægtige, kan falde sammen som et korthus. En revolution kommer, når mennesker overvinder frygten og sammen viser håb om forandring. Oprørernes fremtidsvisioner kan være forskellige, men de er forenet i mistroen til magtens paroler", sagde Daragahi, der understregede, at de arabiske opstande har givet Irans civilsamfund ny energi.

At dømme efter lokale medier, mener alle arabiske Golfstater, at Iran står bag urolighederne i Bahrain. Saudi-Arabien er især bekymret for sin egen shia-befolkning, der 
er koncentreret i den olierige østlige del af kongeriget.

Ahmadinejad afviste på en pressekonference i Teheran erklæringer fra GCC, Golf Samarbejdsrådet: "Vi tillægger dem ingen juridisk værdi, da det er åbenlyst, at de er udformet efter pres fra USA og dets allierede".

Som Boston Globe skrev: "Mundhuggeriet (med Iran) går langt længere tilbage end de seneste alvorlige uroligheder i Bahrain. Det går helt tilbage til 1979-revolutionen, der bragte shia-præsteskabet til magten i Iran. Lige siden har de arabiske lande i Golfen frygtet, at Iran ville ophidse til systemkritik blandt lommerne af shiaer i deres lande, og set med stor bekymring på, at Iran har oprustet og presset sit atomprogram frem".

\section{Tilfældet Bahrain}

Men det er ifølge også lokale medier Bahrain, som har vakt størst bekymring, også længe før de seneste måneders opstande i den arabiske verden. Omkring 70 procent af det lille kongedømmes befolkning er shiaer, men et sunnidynasti har hersket i to århundreder. Og som Boston Globe understreger, har shiaer i årevis protesteret imod diskrimination, samtidig med at regeringen har givet statsborgerskab til sunnier fra andre lande i regionen for at rette op på den demografiske ubalance.

Mens USA opfordrede Bahrain til at svare med reformer, krævede Sau-
di-Arabien, at Bahrain slog hårdt ned på demonstranter.

Der er ingen solide beviser for, at Iran har grebet afgørende ind i Bahrain eller andre arabiske lande. Leder af den shiitiske al-Haq bevægelse, Hassan Mushayma, truede i marts med at hente hjælp fra Iran, hvis saudiske tropper rykkede ind i Bahrain. I juni blev han idømt livsvarigt fængsel for at hævde, at Iran har ret til at støtte Bahrains opposition, når saudiske tropper hjælper med at undertrykke den.

Den russiske avis Pravda har spurgt, hvor alvorligt Hassan Mushaymas trusler skal tages: "Undertrykkelsen af shia-trosfæller fra regimer i den Persiske Golf har altid været en pinefuld sag for Teheran.... Men tør de sætte sig op imod Riyadh, som er amerikansk protektorat?".

Irans potentielt vigtigste redskab imod Saudi-Arabien er titusinder af missiler af kort og mellemlang rækkevidde. De kan skabe alvorlige problemer for den saudiske olieproduktion. Leder af Center for the Study of Modern Iran, Rajab Safarov, har sagt til den russiske netavis Pravda.ru: "Iran kan straffe Saudi-Arabien hårdt for en mulig intervention i Bahrain". Interventionen kom, men hidtil ingen iranske missiler.

Bahrains protestbevægelse blev slået i stykker af arrestation af dets mest aktive ledere og aktivister. Hvor Tunesien og Egypten så forandringer, så Bahrain bare mere af det samme. 


\section{Ret tavst oprør}

Tilbage til Iran, hvor det officielle nyhedsbureau IRNA skrev om begivenhederne på toårsdagen for præsidentvalget, at sikkerhedsstyrkerne arresterede 'nogle personer', der prøvede at forstyrre freden. "Den magtfulde tilstedeværelse af sikkerhedsstyrkerne i Teheran forhindrede nogle få elementer $\mathrm{i}$ at nå deres mål, der styret fra udlandet var at forstyrre samfundets fredelige atmosfære".

Årsdagen blev delvist overskygget af nyheden om den prominente journalist og religiøse aktivist Hoda Sabers død af hjerteslag efter en sultestrejke. Den 54-årige Saber blev fængslet under demonstrationerne i 2009. Saber havde sultestrejket i ti dage i protest imod en anden dissident, Haleh Sahabids død af et hjerteslag efter et sammenstød med sikkerhedsstyrker.

I Iran har demonstrationer igen taget til siden februar. Sørgeceremonier og sportsbegivenheder vendes til demonstrationer imod regimet. Der er også et persisk oprør, selv om det stadig forholder sig relativt tavst, efter at fremdriften i folkelig kamp for frihed overraskende skiftede til den arabiske verden fra slutningen af sidste år

Som en iransk tidligere åbenmundet aktivist siger anonymt: "Vi sidder nu hjemme, slikker sår og finder det egentlig helt urimeligt, at arabere kom før os med at fælde diktatorer”.
$\mathrm{Nu}$ tales meget om behov for tålmodighed blandt regimets mangeartede modstandere i Iran.

Protestbevægelsen har dog "nået sit mål ved at opnå moralsk overtag, ved at vise verden det islamiske regimes sande karakter", fremhæver Ramin Jahanbeeglo. Det har tappet regimet "for meget af dets politiske legitimitet", som ikke mindst gælder i den arabiske verden, hvor Irans ikke længere kan profitere af ry som leder af regionens modstandslejr imod Vesten og Israel.

Regimets vold og splittelsen inden for eliten har svækket Irans image som fortrop for modstand imod undertrykkere af muslimer. Det står øjensynlig klart for de fleste i den arabiske verden, at deres opstande ligner opstanden i Iran i 2009 meget mere, end de ligner Irans islamiske revolution, selv om Teheran kalder det en 'genvækkelse' af ånden fra 79.

Oprøret, der bredte sig fra Iran til den arabiske verden, kan meget vel svinge tilbage i retning af Iran. Og afgørende bliver formentlig, at det iranske regime står over for den samme udfordring, som har væltet regimer i Mellemøsten og Nordafrika: en stadig yngre befolkning. To tredjedele af iranerne er under 30 år.

Vibeke Sperling er udenrigsmedarbejder ved dagbladet Politiken og redaktør af Udenrigs. 